\title{
Sociological Perspectives on Laudato Si’ - Towards a Coherent Social and an Ecological Conversion
}

\author{
Andreja Sršen* \\ asrsen@hrstud.hr \\ https://orcid.org/0000-0003-1667-4651
}

https://doi.org/10.31192/np.19.3.6

UDK / UDC: 502/504:2(044.6)]:316 272-732.2Franciscus, papa

Pregledni članak / Review

Primljeno / Received:

24. ožujka 2021. / March 24, 2021

Prihvaćeno / Accepted:

18. lipnja 2021. / Jun 18, 2021

The article deals with some of the major theoretical and methodological strategies used by sociologists to better understand the relationship between humans and their natural world and to identify the ecologically-relevant features of modern nations and their impact on global climate change. Outlining the current state of sociological knowledge and opportunities for future research about the social causes of global climate change we have to put papal encyclical letter "Laudato Si: On Care for Our Common Home" and global climate change into social light of theoretical insights from the broader discipline of sociology in a number of areas, including micro and macro foundations of social inequality, population and migration research and models of globalization. At the heart of the encyclical Laudato Si', there is a big understanding of human kind, common good and nature where Pope Francis introduces the term of "Integral Ecology" explaining that our nature is created by God and surrounded by the gifts of creation. Accordingly, there is a growing recognition of the need to better incorporate social science analyses into climate change research efforts according to the integral ecology in encyclical Laudato Si'.

Key words: Ecological Conversion, Integral Ecology, Laudato Si, Pope Francis, Sociological Approaches.

\footnotetext{
* Andreja Sršen, Assis. Prof., University of Zagreb, Faculty of Croatian Studies, Department of Sociology; Address: Borongajska cesta 83d; HR-10000 Zagreb, Croatia.
} 


\section{Introduction ${ }^{1}$}

This article deals with new analytical approaches of integral ecology describing these approaches currently employed by sociologists conducting empirical studies of climate change, with an emphasis on analysing a major step forward in predicting the role of the Pope Francis' encyclical Laudato Si'. The purpose of these analytical approaches are threefold: identify ways to 1) increase sociology's capacity to conduct urgent need in international relations for commitment to a human ecology that can favour the growth of an ecology of peace, 2) analyse sociological and theological research that contributes solutions to a proper ecological balance, and 3) expand sociological participation in interdisciplinary research on a set of $»$ Laudato Si' Goals $\aleph^{2}$ in the form of a new integral ecology to reduce our footprint as suggested in the encyclical Laudato Si'. The encyclical letter Laudato Si' (which literally means »Praise be to you«, a phrase taken from St. Francis of Assisi's Canticle of the Creatures), is divided into six chapters and 246 paragraphs, offers a vision for human beings living together in harmony with creation and proposes collaborative approaches, worked out in dialogue between many different sectors of society. It also presents love of beauty as a spiritual practice. St. Augustine claimed that beauty is a name for God, and St. Francis of Assisi has sought the face of God through natural beauty. Sociologists recognize that global climate change is a social problem as much as it is an ethical one, so purely technical responses to climate change will not address the complex social, cultural, and ethical changes that must occur if humans are to successfully confront the potential complex environmental challenges ahead. Human ecology, Pope Francis argues, cannot be separated from the notion of the common good which requires social peace, stability and respect for the human person as well as the overall welfare of society.

\section{Ecological Conversion and Society}

It is obvious that nowadays the social sciences have an important role to play in meeting the issues of climate change as one of the most important issues of

\footnotetext{
${ }^{1}$ Translation and proof-reading by Ana Bačić and Taras Snihura, Ontario College of Teachers, St. Marguerite d'Youville Secondary School, Theology Department.

${ }^{2}$ Measuring Integral Ecology in the spirit of Laudato Si' (Laudato Si' Goals - LSGs): Response to the Cry of the Earth, Response to the Cry of the Poor, Ecological Economics, Adoption of Simple Lifestyles, Ecological Education, Ecological Spirituality and Emphasis on Community involvement and participatory action; The Dicastery for Promoting Integral Human Development, Special Laudato Si' Anniversary Year from 24 $4^{\text {th }}$ May 2020 - 24 $4^{\text {th }}$ May 2021 (24.05.2019); https://www.humandevelopment.va/content/dam/sviluppoumano/documenti/FINAL\%20 EN\%20-\%20Laudato\%20si'\%20Anniv\%20Year\%202020-2021.pdf (23.03.2021).
} 
the $21^{\text {st }}$ century. As the human causes and consequences of climate change have become increasingly apparent, sociologists and theologians have found themselves called upon to contribute to the scientific understanding of the role of humans in promoting intra-generational equity. This equity is closely linked to social justice which requires taking into account the ability of future generations to discharge developmental burdens. In this light, we should find it easy to understand the concerns of Pope Francis for nature, climate change and social inequality. This culminates in a discussion of the encyclical's concept of "ecological conversion" as a way of examining it's call for change at the personal, social and political levels. Bringing Laudato Si' into dialogue with development and a new global inequality Pope Francis critiques the ethics of technology in the modern era:

"The basic problem goes even deeper: it is the way that humanity has taken up technology. and its development according to an undifferentiated and one-dimensional paradigm. This paradigm exalts the concept of a subject who, using logical and rational procedures, progressively approaches and gains control over an external object. This subject makes every effort to establish the scientific and experimental method, which in itself is already a technique of possession, mastery and transformation. ${ }^{3}$

In that light Laudato Si' brings together science and religion as the compatible activities of fallible human beings. Outlining the current state of sociological knowledge and opportunities for future research about the social causes of global climate change we have to put Laudato Si' and global climate change into social light of theoretical insights from the broader discipline of sociology in a number of areas, including research on social movements, political sociology, organizational sociology, micro and macro foundations of social inequality, population and migration research and models of globalization. In that context the National Academy of Science (NAS) Committee on the Human Dimensions of Global Change has produced a number of reports that address various social facets of global climate change. ${ }^{4}$ According to Joane Nagel, Thomas Dietz

\footnotetext{
${ }^{3}$ Pope FRANCIS, Encyclical Letter Laudato Si.' On Care for Our Common Home, May 24, 2015, Vatican City https://www.vatican.va/content/dam/francesco/pdf/encyclicals/documents/ papa-francesco_20150524_enciclica-laudato-si_en.pdf (0507.2021), 78-79; Papa FRANJO, Laudato sì. Enciklika o brizi za zajednički dom, 24. svibnja 2015., Dokumenti, br. 169, Zagreb, Kršćanska sadašnjost, 2015.

${ }^{4}$ Cf. THE NATIONAL ACADEMIES, The 2008 Highlights of National Academies Reports; summary report, Understanding and Responding to Climate Change, (2008); National Academies Reports identify several areas as crucial for scientific investigation: 1) human activities that alter the earth's environment; 2) forces that drive these activities; 3 ) consequences of environmental changes for societies and economies; and 4) how humans respond to these changes; https://www.preventionweb.net/files/2276_climatechangefinal.pdf (19.03.2021); National Academies Committee on the Human Dimensions of Global Change reports; https://www. nap.edu/initiative/committee-on-the-human-dimensions-of-global-change (19.03.2021).
} 
and Jeffrey Broadbent ${ }^{5}$ and building on social theories like Allan Schnaiberg's »Treadmill of Production $\ll^{6}$, John Bellamy Foster's »Metabolic Rift $\aleph^{7}$ and Marina Fischer-Kowalski's »Social Metabolism ${ }^{8}$, political economy analyses link carbon emissions and their effect on the global climate to economic and social organization in modern industrial societies. ${ }^{9}$

Hereby, authors ${ }^{10}$ represent some of the major theoretical and methodological strategies used by sociologists to better understand the relationship between humans and their natural world and to identify the ecologically-relevant features of modern industrial nations and their impact on global climate change. In Table 1 we can see significant contributions to climate change research fields in the encyclical Laudato Si' and strategies used by sociologists ${ }^{11}$ in this matter:

Table 1. Contributions to climate change research fields

\begin{tabular}{|l|l|}
\hline $\begin{array}{l}\text { Climate change research fields used by } \\
\text { sociologists }\end{array}$ & $\begin{array}{l}\text { Climate change research fields used in the } \\
\text { encyclical Laudato Si' }\end{array}$ \\
\hline Political Economy & Global inequality \\
\hline $\begin{array}{l}\text { Human Ecology and Environmental Impact } \\
\text { Models }\end{array}$ & Pollution and Climate Change \\
\hline $\begin{array}{l}\text { Stratification and Status-Attainment Effects } \\
\text { on Production and Consumption }\end{array}$ & Environmental, economic and social ecology \\
\hline Cultural and Meaning Systems & Integral ecology / Cultural ecology \\
\hline
\end{tabular}

In a comparison with climate change research fields used by sociologists and climate change research fields used in the encyclical Laudato Si' listed in the Table 1, it is obvious that the sociological themes of climate change are compatible with the papal encyclical Laudato Si'. Furthermore, we can see in Table 1 that the connection between climate change and global inequality is a complex one in many ways, especially in the multidimensional understanding of human life in economic growth.

\footnotetext{
${ }^{5}$ Joane NAGEL, Thomas DIETZ, Jeffrey BROADBENT, Workshop on Sociological Perspectives on Global Climate Change, National Science Foundation, American Sociological Association, 2010, 17.

${ }^{6}$ Allan SCHNAIBERG, The Environment: From Surplus to Scarcity, Oxford University Press, 1980; see also: Kenneth GOULD, David PELLOW, Allan SCHNAIBERG, The Treadmill of Production: Injustice and Unsustainability in the Global Economy, Paradigm Publishers, 2008.

${ }^{7}$ John BELLAMY FOSTER, Marx's Theory of Metabolic Rift: Classical Foundations for Environmental Sociology, American Journal of Sociology, 105 (1999) 2, 366-405.

${ }^{8}$ Marina FISCHER-KOWALSKI, H. HABERL, Socioecological Transitions and Global Change. Trajectories of Social Metabolism and Land Use, Edward Elgar Publishing, 2007.

${ }^{9}$ Cf. Nagel, Dietz, Broadbent, Workshop on Sociological Perspectives..., 18.

${ }^{10}$ Cf. ibid., 14.

${ }^{11}$ To advance sociological research on global climate change, the National Science Foundation (NSF) funded atwo-day workshop in 2008 which brought together 40 sociology faculty, graduate students, and policy experts. Nagel, Dietz, Broadbent, Workshop on Sociological Perspectives..., 13-25.
} 


\section{The Concept of the »Common Good»}

Sociology can contribute to several ways to Catholic social thought on the common good, because the common good is central to the social encyclicals and pastoral letters that make up official Catholic social teaching. ${ }^{12}$ Regarding rationality, the Church already is close to the sociological approach and opposed to the individualism that characterize the consumerism mentality. In this respect then, sociology can deepen Catholic social thought. The truth is that the religions share a narrative of responsibility toward the earth and the poor. Perhaps the most valuable contribution of religions is in the terms of »common good» and »common home« they have developed for resolving important outcomes that are foundational for social order and individual flourishing. It helps us understand why political and economic stability have been so rare throughout history. It also highlights some of the effects of any activity producing global problems such as contamination, climate change, and the loss of biodiversity.

Nowadays, we are afforded new challenges for understanding the common good in a cross-disciplinary conversation between sociology and theology. This requires a significant list of challenges that will confront that dialogue. First, cross-disciplinary discussions can contribute to better theorizing about human nature and society. Sociological and theological approaches to the common good generally emphasize how human beings are embedded in social relationships - from the family to the nation. A greater attention to the social nature of human beings could provide an important corrective in approaches to the common good. It reminds us that humanity's social nature does not generate a straightforward pursuit of a collaborative human society. Indeed, producing a just social order that maximizes the fullest flourishing of all its members seems to be complicated. Thus, a dialogue on the common good between sociology and theology should push us to think about how a bounded understanding of democracy, the political dynamics of international trade and intergovernmental relations can both encourage and temper the project of the common good. The definition of the common good does not speak simply about individuals finding their own fulfilment but also of social groups doing so. This speaks to the way that we should not think simply as individuals or the state, but also as intermediary communities like family, unions, churches and other social organizations. It is a reminder that pluralism needs to respect not just a variety of individual beliefs but also a variety of communal ways of life. Not only the concept of the »common good» in Catholic social thought is traditionally

\footnotetext{
${ }^{12}$ Cf. Charles K. WILBER, Contributions of Economic Theory to an Understanding of the Common Good in Catholic Social Thought, in: Daniel K. FINN (ed.), Empirical Foundations of the Common Good. What Theology Can Learn from Social Science, Oxford University Press, 2017, 114-142, 116.
} 
understood within the context of a specific community or nation, but also as economic and political systems. This way requires communities and nations to look beyond their own borders when considering how policies have an impact on the common good and human well-being.

What common good means in the Catholic notion? First, common good is rooted in a communitarian vision of society emphasizing the dignity of the human person and, the essentially, social nature of that dignity. Therefore, the common good is central to the social encyclicals and pastoral letters that make up official Catholic social teaching. For example, the pastoral letter on economy sent by the Holy Father Francis for the event »Economy of Francesco" (Assisi, 26-28 March 2020) argues that we, as individuals and society as well, »need to correct models of growth incapable of guaranteeing respect for the environment, openness to life, concern for the family, social equality, the dignity of workers and the rights of future generations. $\aleph^{13}$ In addition, Pope Francis points out that there is a need to "re-animate " today's economy and to give a soul to the economy of tomorrow. Therefore, every perspective on economic life that is human must be shaped by the question - how does the economy think about human flourishing? The answer on this question is very much related to one component of human flourishing in the economy - it is freedom. This argument is not based on an idea that all individuals may do whatever they wish, but on concept of freedom drawn from Catholic social thought.

There are some attempts in putting concept of freedom, drawn from Catholic social thought, and human flourishing together:

»Freedom has three dimensions: autonomy, immunity and empowerment. Autonomy has to do with freedom of choice. Immunity has to do with the absence of coercion. It is, in brief, negative freedom (that is to say "freedom from") cited by Isaiah Berlin. Empowerment, in the sense given to it by Amartya Sen, has to do with the capability to choose - that is to say to reach goals that are set, at least in part, by the person himself. One is not free if one is never (at least partially) able to fulfil one's own life plan. ${ }^{14}$

Finally, avoiding moral judgments in economics as a discipline the question «what is» should be understood by theologians and sociologists with the question «what ought to be». We have to be aware of the fact that economic systems are a human creation and, as such, these systems solve certain problems for us while creating others. Accordingly, economic analysis can enrich the common good practise in four ways:

\footnotetext{
${ }^{13}$ Cf. Pope FRANCIS, Letter Sent by the Holy Father for the Event »Economy Of Francesco «, Assisi, 26-28 March 2020; http://www.vatican.va/content/francesco/en/letters/2019/documents/ papa-francesco_20190501_giovani-imprenditori.html (19.03.2021).

${ }^{14}$ Stefano ZAMAGNI, Restore the Common Good: Pope Benedict XVI's Message to Economists, ABC Religion and Ethics, (20.02.2013); http://www.abc.net.au/religion/articles/2013/02/20/3694739.htm (23.03.2021).
} 
"first, economics embodies a deep respect for economic agency and for the effects of policy and institutions on individual agents (...) Its models are founded on individual action in pursuit of goals (...) the second contribution of economics is its awareness and exploration of this unintended order. One need not believe that the order of a free economy is desirable in every way to admit that it exists, that it is in important ways undirected, and that we should analyse it (...) a third contribution is the economic analysis of the various kinds of goods (private, public, common pool resources) and the advisability of public versus private provision of these goods (...) a fourth contribution is recent work on the logic of institutions and norms (...) the work of Vernon Smith on the evolution of exchange institutions, of Robert Sugden and others on the development of norms, and of Elinor Ostrom on sustainable institutional solutions to commons problems keeps the good of the individual at the center of the analysis while improving our understanding of social interconnectedness. ${ }^{15}$

There are some explanations where »economists insist that human agency is a driving force in markets and society, they have developed models of complex social interaction in which individual agency is foundational. ${ }^{16}$ The encyclical Laudato Si' lays out very clearly that the effects of environmental degradation will also impact developing economies the most:

»Many of the poor live-in areas particularly affected by phenomena related to warming, and their means of subsistence are largely dependent on natural reserves and eco-systemic services such as agriculture, fishing and forestry. They have no other financial activities or resources which can enable them to adapt to climate change or to face natural disasters, and their access to social services and protection is very limited. ${ }^{17}$

Accordingly, climate changes involve interactions of social and economic variables at different level where economists still adopt an incomplete account of human fulfilment. It may appear at first glance that Laudato Si' is indeed promoting an antibusiness rhetoric, as there are numerous places where pope Francis does criticize business. The President of the Pontifical Council for Justice and Peace, Cardinal Peter Turkson in a conference on »Care for our Common Home in the context of Large Scale Investments in Mining and Agriculture« in Lusaka, Zambia, said in his remarks that Pope Francis »is not anti-business « remainding us how "profit has its role in sustaining an enterprise and allowing it to improve and innovate. Pope Francis calls upon business to lead by harnessing its creativity to solve pressing human needs. ${ }^{18}$

\footnotetext{
${ }^{15}$ Andrew M. YUENGERT, What can Economists Contribute to the Common Good Tradition, in: Daniel K. FINN (ed.), Empirical Foundations of the Common Good. What Theology Can Learn from Social Science, Oxford University Press, 2017, 36-64, 39.

${ }^{16}$ Yuengert, What can Economists Contribute..., 39.

${ }^{17}$ LS, 25.

${ }^{18}$ Cardinal Peter TURKSON, An Overview of Laudato si' - What are the main issues and key concerns?, (25.04.2016); http://www.archivioradiovaticana.va/storico/2016/04/25/cardinal_turkson_pope_francis_is_not_anti-business/en-1225335 (25.03.2021).
} 


\section{Towards a Coherent Social and an Ecological Conversion}

Perhaps more than any previous encyclical, Laudato Si' is addressed to individual persons calling each of us to self-examination. The structure of Laudato Si' also demands a shift in our understanding of our place in the world and our relationship to the other creatures of the earth, and it points to the need for concrete action in the form of a changed lifestyle as well as social activism. Emphasizing the role of individuals in generating carbon emissions - who are thus held responsible for reducing them - fits well with the Western and particularly American emphasis on individualism. ${ }^{19}$ Some theories look to values as the basis of environmentalism. Some authors suggest that it is an expression of postmaterialist values of quality of life and self-expression that emerge as a result of increasing affluence and security in the developed countries. ${ }^{20}$ Environmentally significant behaviour can reasonably be defined by its impact: the extent to which it changes the availability of materials or energy from the environment or alters the structure and dynamics of ecosystems or the biosphere itself. $^{21}$

In addition to 800 years of Franciscan education, we are still called to ecological conversion. This conversion should be conducted at the global scale, about energy, climate and sustainable development. In an article prepared for the $10^{\text {th }}$ Whitehead International Conference and published in For Our Common Home: Process-relational Responses to Laudato Si', some authors indicate that Laudato Si' challenges us to implement three major shifts:

»From narrow anthropocentrism to integral ecology, centred on the common good and the interconnectedness and dignity of all life. Toward a just and equitable social order, emphasizing a new bottom line for development that replaces economic growth and short-term gain (GDP) with fuller measures of personal and planetary wellbeing. Toward a true global collaboration-a social movement that is not about conversion, but convergence grounded in shared global ethics.$^{22}$

According to this global collaboration some authors indicate that 90 percent of the media coverage focused on climate change yet note that only ten percent of the document actually addresses that topic where they take issue

\footnotetext{
${ }^{19}$ Cf. Seymour Martin LIPSET, American Exceptionalism: A Double-Edged Sword, New York, W. W. Norton \& Company, 1997, 749-757.

${ }^{20}$ Cf. Paul C. STERN, New Environmental Theories: Toward a Coherent Theory of Environmentally Significant Behavior, Journal of Social Issues, 56 (2002) 3, 407-424.

${ }^{21}$ Cf. Paul C. STERN, Toward a working definition of consumption for environmental research and policy, in: Thomas DIETZ et al. (eds.), Environmentally significant consumption: Research directions, Washington, National Academy Press, 1997, 12-25, 14-15.

${ }^{22}$ John B. COBB Jr., Ignacio CASTUERA (eds.), For our common home: Process-relational responses to Laudato Si', Anoka, Process Century Press, 2015, 202.
} 
with Francis on six points: poverty, fossil fuels, markets, science and consensus, adaptation, and the precautionary principle. ${ }^{23}$ They argue that:

»(..) the encyclical is coloured too much by a harkening for a past world, prior to the Industrial Revolution, which is assumed to have been generally simpler, cleaner, and happier. There is little historical evidence for such a vision, and for most people then life was brief, painful[ly] poor, and even brutal«. ${ }^{24}$

Yet while the document did receive criticism, Pope Francis nevertheless established a new standard bearer for some-in the preface to a compendium of articles on integral ecology, John B. Cobb, Jr. says:

"The pope's primary audience was not the elite in the church or in the wider world. He addressed the world's people. And millions have resonated [with] Francis' call. Before then, we had scores of leaders working for rational change, and therefore, effectively, no leader at all. Now the cause of life has a champion who cannot be ignored «. ${ }^{25}$

Some authors show how the Dominant Social Paradigm fails to support global sustainability goals, and then contrast it with the New Ecological Paradigm which calls for a more eco-centric and holistic view of the world evaluating programs developed by organizations like the OECD, the UN Global Compact. ${ }^{26}$ According to Catton \& Dunlap there are four identified assumptions for the Dominant Social Paradigm:

»1. that human persons are independent and inherently different from nature, and so are dominant over it; 2 . that they are in control of their own futures; 3 . that the world has unlimited potential for creating opportunities for human persons; and 4. that human progress can be maintained by human ingenuity, often in the form of technology«. ${ }^{27}$

Such assumptions influence the way in which sociologists approach their subject matter and practice their craft. Accordingly, to understand the discipline of sociology it is important to identify »deepest assumptions about man and society« where Gouldner's analysis of these assumptions are quite similar to Ritzer's analysis of $"$ paradigm $\ll^{28}$ Ritzer points out that sociological work

${ }^{23}$ Cf. Allen P. TROPEA-GRAY, Pope Francis, Laudato Si', and Integral Ecology: Perspectives on a Critical Issue, Journal of Management for Global Sustainability, 5 (2017) 1, 1-18, 2.

${ }^{24}$ Peter FOSTER, Bernard DONOUGHUE, The papal encyclical: A critical Christian response, The Global Warming Policy Foundation; https://www.thegwpf.org/content/uploads/2015/07/ Forster-Donoughue1.pdf (20.03.2021).

${ }^{25}$ Cobb, Castuera (eds.), Preface, For our common home..., 203.

${ }^{26}$ Cf. Tropea-Gray, Pope Francis, Laudato Si, and Integral Ecology..., 9.

${ }^{27}$ William R. CATTON Jr., Riley E. DUNLAP, A New Ecological Paradigm for Post-Exuberant Sociology, American Behavioral Scientist, 24 (1980) 1, 15-47; in: Ann-Marie KENNEDY \& Nicholas J. C. SANTOS, The Papal Encyclical Laudato Si' - a Focus on sustainability attentive to the poor, Journal of Management for Global Sustainability, 5 (2017) 1, 114.

${ }^{28}$ Alvin W. GOULDNER, The Coming Crisis of Western Sociology, New York, Basic Books, 1970, 28. 
cannot be classified primarily on the basis of its theories, but rather on the basis of the characteristics of the metaphysical paradigm to which it belongs. ${ }^{29}$ It serves to define what should be studied, what questions should be asked, how they should be asked, and what rules should be followed in interpreting the answers obtained. The paradigm is the broadest unit of consensus within a science and serves to differentiate one scientific community (or subcommunity) from another. It subsumes, defines, and interrelates the exemplars, theories, and methods and instruments that exist within it. ${ }^{30}$ Most sociological theories can be seen as stemming from one of three broad paradigms within the discipline: the »social facts« paradigm derived from Durkheim, the »social definition " paradigm derived from Weber, and a newer (and, so far, less influential) »social behaviour « paradigm derived from the behavioural psychologist Skinner. ${ }^{31}$

From this point of view Pope Francis's encyclical Laudato Si' is calling for four distinct levels of change: a religious change, a moral change, a cultural change and a social change. All these changes challenge the dominant technocratic paradigm and each of these aspects flows from what the encyclical refers to as »ecological conversion«. For some authors »eco-centrism emphasizes a belief in holism rather than in atomism, thereby helping the eco-centrist to understand that human persons are part of a larger whole and are thus limited in what they can do. ${ }^{32}$ These authors conclude with two main assumptions: a) that the base assumptions of the Dominant Social Paradigm and New Ecological Paradigm are considerably different; b) Laudato Si' provides a starting point for business and society to begin implementing more humane and sustainable practices and change their thinking regarding sustainability. ${ }^{33}$ The Holy Father reminds all men and women of good will that »the human environment and the natural environment deteriorate together; [that] we cannot adequately combat environmental degradation unless we attend to causes related to human and social degradation. ${ }^{34}$ In his discussion of St. Francis of Assisi, he specifically notes that St. Francis is best characterized as an ontological poet and a nature mystic who discovered the transformative power of the universe.

\footnotetext{
${ }^{29}$ Cf. George RITZER, Reflections on the Paradigmatic Status of Sociology, Mid-American Review of Sociology, 3 (1978) 2, 1-15, 2-3.

${ }^{30}$ Cf. ibid., 4-5.

${ }^{31}$ Catton, Dunlap, A new ecological paradigm..., 23-24.

${ }^{32}$ Kennedy, Santos, The Papal Encyclical Laudato Si'..., 112.

${ }^{33}$ Cf. ibid., 129.

${ }^{34} \mathrm{LS}, 48$.
} 


\section{Conclusion}

The climate change problem is global. It can only be solved through integrated governance systems at multiple levels: regional, national, and global. Since sociology possesses considerable knowledge of social and cultural systems, it has a great deal to offer in helping understand the societal origins of climate change, as well as how social, economic, political and cultural factors adopt to climate change. Arguably, sociologists have been slow in engaging with climate change because of the social theoretical consideration of climate change revolves around a handful of slow-moving, essentially classic problems. As such, sociologists tend to frame climate change as an ethical and social issue. Laudato $\mathrm{Si}^{\prime}$ is Pope Francis' historic encyclical on care for creation and our common home, calling for »ecological conversion«, changes in lifestyle and society, and strong political action. Laudato Si' proposes collaborative approaches to pursue a vision of protecting the planet and human flourishing. These approaches propose a whole series of dialogues about the direction of human flourishing. This dialogue must include transparent decision-making so that the politics serve human fulfilment and not just economic interests. Today, in the $21^{\text {st }}$ Century, more than in any prior papal encyclical St. Francis of Assisi is promoted as an example for Christian living, presented an example par excellence of integral ecology, both of which are concepts introduced and emphasized in the papal encyclical Laudato Si'.

Lastly, in Laudato Si' care for the poor and care for the Earth are presented as inter-related, showing how inseparable the bond is between concern for nature, questions of human wellbeing and social justice, and protecting the planet and human flourishing. Laudato Si' integrates all of these themes. The response of sociology and theology to the environmental crisis -and to the social forces of industrialization, globalization and consumerism that are causing this crisisis the most important factor determining whether religion will be a vital part of the future of humanity or will instead sink into increasing irrelevance. 


\section{Andreja Sršen* \\ Sociološke perspektive enciklike Laudato Si' - prema cjelovitom socijalnom $i$ ekološkom obraćenju \\ Sažetak}

Rad obrađuje neke od glavnih teorijskih i metodoloških strategija koje sociolozi koriste za bolje razumijevanje odnosa između ljudi i njihova prirodnoga svijeta, prepoznajući važne ekološke značajke suvremenih nacija i njihova utjecaja na globalne klimatske promjene. Iznoseći trenutne sociološke spoznaje i mogućnosti za buduća istraživanja društvenih uzroka globalnih klimatskih promjena, svakako treba razmotriti encikliku pape Franje Laudato Si' - o brizi $z a$ naš zajednički dom i globalne klimatske promjene u okviru socijalnih teorija kroz šire područje sociologije koja uključuje mikro i makro osnove socijalne nejednakosti, istraživanje populacije te modele globalizacije. U središtu enciklike Laudato Si' pronalazimo veliko razumijevanje za čovječanstvo, za pojam općeg dobra i prirode, gdje papa Franjo, uvodeći pojam »cjelovite ekologije«, tumači čovjekovu prirodu koja proizlazi od Stvoritelja te je okružena darovima stvaranja. Sukladno tomu, sve se više prepoznaje potreba za boljim uključivanjem društvenih znanosti u istraživanja klimatskih promjena u skladu s cjelovitom ekologijom enciklike Laudato Si'.

Ključne riječi: ekološko obraćenje, cjelovita ekologija, Laudato Si', papa Franjo, sociološki pristupi.

\footnotetext{
* Doc. dr. sc. Andreja Sršen, Sveučilište u Zagrebu, Fakultet hrvatskih studija, Odsjek za sociologiju; Borongajska cesta 83d; HR-10000 Zagreb; e-mail: asrsen@hrstud.hr.
} 